Note

\title{
OCCURRENCE OF Dinarmus basalis IN Callosobruchus analis IN STORED SOYBEAN IN SÃO PAULO, BRAZIL
}

\author{
Valmir Antonio Costa ${ }^{1 *}$; Élio César Guzzo ${ }^{2}$; André Luiz Lourenção ${ }^{3}$; Márcio Aurélio Garcia \\ Correia Tavares ${ }^{2}$; José Djair Vendramim ${ }^{4}$ \\ ${ }^{1}$ Instituto Biológico/APTA - C.P. 70 - 13001-970 - Campinas, SP - Brasil. \\ ${ }_{3}^{2}$ USP/ESALQ - Programa de Pós-Graduação em Entomologia. \\ ${ }^{3}$ Instituto Agronomico de Campinas/APTA - C.P. 28 - 13001-970 - Campinas, SP - Brasil. \\ ${ }^{4}$ USP/ESALQ - Depto. Entomologia, Fitopatologia e Zoologia Agrícola - C.P. 09 - 13418-900 Piracicaba, SP - \\ Brasil. \\ *Corresponding author<valmir@biologico.sp.gov.br>
}

\begin{abstract}
Callosobruchus analis (F.) is considered an important pest in several countries in Africa, Asia and Oceania. It has been observed infesting seeds belonging to 15 Leguminosae genera, including peanut, bean, chickpea, pea, cowpea, and soybean. One of its main natural enemies is the parasitoid Dinarmus basalis (Rondani) (Hymenoptera: Pteromalidae), whose control efficiency has already been demonstrated in several studies. This paper records the occurrence of $C$. analis and its parasitoid, $D$. basalis, in stored soybean of the state of São Paulo, Brazil.

Key words: Glycine max, Hymenoptera, Pteromalidae, Coleoptera, Bruchidae

\section{OCORRÊNCIA DE Dinarmus basalis (RONDANI) EM Callosobruchus analis (F.) EM SOJA ARMAZENADA EM SÃO PAULO, BRASIL}

\begin{abstract}
RESUMO: Callosobruchus analis (F.) é uma praga de expressão econômica em diversos países da África, Ásia e Oceania. Já foi observado infestando sementes de espécies de leguminosas pertencentes a 15 gêneros, incluindo-se culturas como amendoim, grão-de-bico, feijão, ervilha, caupi e soja. Um de seus inimigos naturais mais importantes é o parasitóide Dinarmus basalis (Rondani) (Hymenoptera: Pteromalidae), cuja eficiência de controle já foi demonstrada em vários estudos. Neste trabalho registra-se a ocorrência de $C$. analis e de seu parasitóide, D. basalis, em grãos armazenados de soja no estado de São Paulo.

Palavras-chave: Glycine max, Hymenoptera, Pteromalidae, Coleoptera, Bruchidae
\end{abstract}

In Brazil, the following bruchid species are referred as important pests of stored grain pests: Acanthoscelides obtectus (Say) in Phaseolus vulgaris and P. lunatus; Zabrotes subfasciatus (Boh.) and Callosobruchus maculatus (F.) in P. vulgaris, P. lunatus and some Vigna species; and C. phaseoli (Gyll.) in Vigna spp., Cicer arietinum, and Dolichos lablab (Athié \& Paula, 2002; Gallo et al., 2002). Another bruchid that also infests legumes in Brazil is Callosobruchus analis (F.), reported infesting $V$. unguiculata seeds in the northern and northeastern regions of the country (Bastos, 1968; Silva \& Magalhães, 1980). In Africa, Asia, and Oceania, C. analis is considered a pest of economic expression for stored legume grains (Southgate, 1979). This pest has been observed infesting seeds of 15 genera, including peanut, chickpea, bean, pea, cowpea, and soybean (Waterworth, 1986). Therefore, this study involves the record of the presence of $C$. analis and one of its parasitoids, in the State of São Paulo, Brazil.
In January 2003, during an inspection in a seed storage facility at the Instituto Agronômico (IAC), Campinas, São Paulo State, bruchids were found infesting soybean seeds. The facility had no control of temperature, relative humidity and photoperiod. Live adults were taken to the laboratory, at $27^{\circ} \mathrm{C}$, relative humidity around $70 \%$ and natural photoperiod, and placed in vials containing seeds of the infested cultivars to confirm that the species could be reared on soybean. Upon emergence, adults of the filial generation were sent to Dr. John M. Kingsolver, Florida State Collections of Arthropods, Florida, USA, who identified them as belonging to the species $C$. analis. Next, studies were initiated in the laboratory to evaluate whether soybean cultivars were suitable for the development of this species.

The emergence of Dinarmus basalis (Rondani) (Hymenoptera: Pteromalidae) was observed in the rearing vials. This is a solitary, idiobiont ectoparasitoid of 
immatures and even recently-formed adults of several bruchid species that develop on legumes (Verma, 1991). The females are synovigenic, i.e., they produce eggs during the entire adult stage (Nishimura, 1993) and can actively move within the column of stored grains in search for seeds containing larvae of their hosts (Gauthier et al., 1999).

Parasitism of $D$. basalis in $C$. chinensis on Vigna radiata had already been verified in Brazil in the state of Santa Catarina (Lima, 1942), in C. maculatus on $V$. unguiculata in Pará (Ohashi et al., 1993), and in A. obtectus in the northeastern region (Oliveira, 1948); the present communication, however, is the first record of the association of this parasitoid with $C$. analis in the country and also of the occurrence of both in the State of São Paulo. D. basalis probably occurs all across Brazil, because although the species has its origin in Africa, it has spread throughout the Americas, Asia, and Europe, due to grain and seed trading (Rasplus, 1989).

In South America, D. basalis also occurs in $Z$. subfasciatus; in the rest of the world, in addition to the five hosts already mentioned, it is found parasitizing Bruchidius atrolineatus (Pic), several species of Bruchus and Callosobruchus (Coleoptera: Bruchidae) (Rasplus, 1989), and other coleopterans.

The effectiveness of $D$. basalis in the biological control of $C$. maculatus, C. chinensis, and $B$. atrolineatus was demonstrated experimentally, but the success depends on the storage conditions (Islam \& Kabir, 1995, Ouedraogo et al., 1996, Sanon et al., 1998).

Additional parasitism studies for our conditions are extremely important to make integrated bruchid control in stored grains viable, since studies on the use of $D$. basalis in association with plant varieties resistant to several bruchid species (Schmale et al., 2003), insecticidal plants (Boeke et al., 2003), as well as other parasitoids already exist in other countries (Gauthier et al., 1999; Huis et al., 2002).

\section{ACKNOWLEDGMENTS}

To Dr. John M. Kingsolver, from the Florida State Collections of Arthropods, Florida, USA, for identifying $C$. analis.

\section{REFERENCES}

ATHIÉ, I.; PAULA, D.C. Insetos de grãos armazenados: aspectos biológicos e identificação. 2.ed. São Paulo: Varela, 2002. 244p.

BASTOS, J.A.M. Influência das embalagens no controle do gorgulho Callosobruchus analis em feijão de corda, Vigna sinensis. Turrialba, v.18, p.76-79, 1968.
BOEKE, S.J.; SINZOGAN, A.A.C.; ALMEIDA, R.P. de; BOER, P.W.M. de; JEONG, G.; KOSSOU, D.K.; LOON, J.J.A. van. Side-effects of cowpea treatment with botanical insecticides on two parasitoids of Callosobruchus maculatus. Entomologia Experimentalis et Applicata, v.108, p.43-51, 2003.

GALLO, D.; NAKANO, O.; SILVEIRA NETO, S.; CARVALHO, R.P.L.; BAPTISTA, G.C. de; BERTI FILHO, E.; PARRA, J.R.P.; ZUCCHI, R.A.; ALVES, S.B.; VENDRAMIM, J.D.; MARCHINI, L.C.; LOPES J.R.S.; OMOTO, C. Entomologia agrícola. Piracicaba: FEALQ, 2002. 920p.

GAUTHIER, N.; SANON, A.; MONGE, J.P.; HUIGNARD, J. Interspecific relations between two sympatric species of Hymenoptera, Dinarmus basalis (Rond) and Eupelmus vuilleti (Crw.), ectoparasitoids of the bruchid Callosobruchus maculatus (F). Journal of Insect Behavior, v.12, p.399-413, 1999.

HUIS, A. van; ALEBEEK, F.A.N. van; ES, M. van; SAGNIA, S.B. Impact of the egg parasitoid Uscana lariophaga and the larval-pupal parasitoid Dinarmus basalis on Callosobruchus maculatus populations and cowpea losses. Entomologia Experimentalis et Applicata, v.104, p.289-297, 2002.

ISLAM, W.; KABIR, S.M.H. Biological control potential of Dinarmus basalis (Rond.) (Hymenoptera: Pteromalidae), a larval-pupal ectoparasitoid of the pulse beetle, Callosobruchus chinensis (L.). Crop Protection, v.14, p.439-443, 1995.

LIMA, A.D.F. Mais um inimigo do Callosobruchus chinensis. Boletim da Sociedade Brasileira de Agronomia, v.5, p.441-443, 1942.

NISHIMURA, K. Oviposition strategy of the parasitic wasp Dinarmus basalis (Hymenoptera, Pteromalidae). Evolutionary Ecology, v.7, p.199-206, 1993.

OHASHI, O.S.; COUTINHO, J.C.B.; SILVA, O.F. Aspectos biológicos de Dinarmus basalis (Rondani, 1877) (Hymenoptera: Pteromalidae) ectoparasito de Callosobruchus maculatus (Fabricius, 1775) (Coleoptera: Bruchidae). Anais da Sociedade Entomológica do Brasil, v.22, p.161-167, 1993.

OLIVEIRA, M.A. de. Contribuição ao estudo do combate biológico do gorgulho do feijão (Acanthoscelides obsoletus Say), pelo Bruchobius laticeps Ash. Agros, v.1, p.258-268, 1948.

OUEDRAOGO, P.A.; SANON, A.; MONGE, J.P.; TRAN, B.M.D.; HUIGNARD, J.; CREDLAND, P.F. Influence of temperature and humidity on populations of Callosobruchus maculatus (F.) (Coleoptera: Bruchidae) and its parasitoid Dinarmus basalis (Rond.) (Pteromalidae) in two climatic zones of Burkina Faso. Bulletin of Entomological Research, v.86, p.695-702, 1996.

RASPLUS, J.Y. Révision des espèces afrotropicales du genre Dinarmus Thomson (Hymenoptera: Pteromalidae). Annales de la Société Entomologique de France (N.S.), v.25, p.135-162, 1989.

SANON, A.; OUEDRAOGO, A.P.; TRICAULT, Y.; CREDLAND, P.F.; HUIGNARD, J. Biological control of bruchids in cowpea stores by release of Dinarmus basalis (Hymenoptera: Pteromalidae) adults. Environmental Entomology, v.27, p.717-725, 1998.

SCHMALE, I.; WACKERS, F.L.; CARDONA, C.; DORN, S. Combining parasitoids and plant resistance for the control of the bruchid Acanthoscelides obtectus in stored beans. Journal of Stored Products Research, v.39, p.401-411, 2003.

SILVA, A.B.; MAGALHÃES, B.P. Insetos nocivos à cultura do feijão caupi (Vigna unguiculata) no Estado do Pará. Belém: EMBRAPACPATU, 1980. 22p. (Boletim de Pesquisa, 3).

SOUTHGATE, B.J. Biology of the Bruchidae. Annual Review of Entomology, v.24, p.449-473, 1979.

VERMA, R. Life history and some aspects of biology of Dinarmus basalis (Hymenoptera, Pteromalidae), a parasite of stored legume bruchids. Acta Entomologica Bohemoslovaca, v.88, p.359-366, 1991.

WATERWORTH, P.D. (Ed.). Internal seed infesting insects. Part I e II. Beltsville: USDA, 1986. 136p.

Received November 10, 2006

Accepted March 30, 2007 